\title{
Micranoic Acids A and B: Two New Octanortriterpenoids from Schisandra micrantha
}

\author{
Rong-Tao Li, Quan-Bin Han, Ai-Hua ZHAO, and Han-Dong SuN* \\ State Key Laboratory of Phytochemistry and Plant Resources in West China, Kunming Institute of Botany, Chinese \\ Academy of Sciences; Kunming 650204, PR China. Received July 13, 2003; accepted August 6, 2003
}

Two novel octanortriterpenoids, micranoic acids $A$ (1) and B (2), along with three known compounds, kadsuric acid (3), 3 $\beta$-hydroxy-lanost-9(11),24(25)-dien-26-oic acid (4) and schizandronic acid (5), were isolated from the leaves and stems of Schisandra micrantha. The structures of 1 and 2 were determined by 1D and 2D NMR spectroscopic analysis. Micranoic acids A and B represent a new group of triterpenes in which the entire C-17 side chain has lost. This is the first report of octanortriterpenoids isolated from the family Schisandraceae.

Key words Schisandra micrantha; Schisandraceae; octanortriterpenoid; micranoic acid A; micranoic acid B

Much attention has been focused on the family Schisandraceae because lignans isolated from this family showed various biological activities. ${ }^{1,2)}$ It has been reported that several species of this family contain triterpenoids. ${ }^{1)}$ Our previous phytochemical study on Schisandra sphaerandra resulted in the discovery of nigranoic acid (7), which showed activity on several anti-HIV reverse transcriptase and polymerase assays. ${ }^{3)}$ In continuation of our investigation on Schisandraceae species, we examined the chemical constituents of Schisandra micrantha A. C. SмIтH, a plant indigenous to Yunnan Province of China. In the preceding paper, we have described the isolation of a novel nortriterpene, micrandilactone A with a unique skeleton, from the EtOAc extract of the leaves and stems of this plant. ${ }^{4}$ Further studies on its analogues in the petroleum ether extract of the same source led to the isolation of two novel octanortriterpenes, micranoic acids A (1) and B (2), along with three known compounds: kadsuric acid (3), ${ }^{5}$ 3 $\beta$-hydroxy-lanost-9(11),24(25)-dien-26oic acid $(4)^{6}$ and schizandronic acid (5). ${ }^{7)}$ The structural elucidation of 1 and 2 and proposed biogenetic pathways of these five compounds are reported in this paper.

\section{Results and Discussion}

Micranoic acid A (1) analyzed for $\mathrm{C}_{22} \mathrm{H}_{32} \mathrm{O}_{3}$ by high reso-

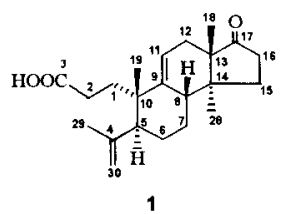

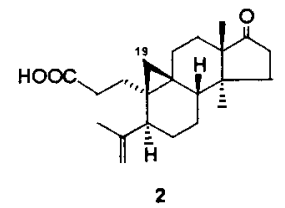

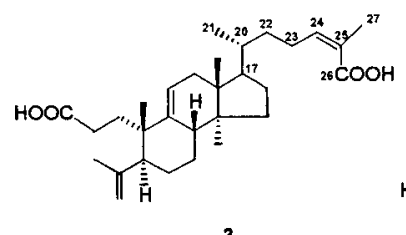

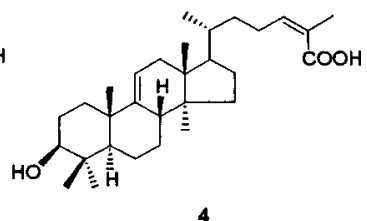

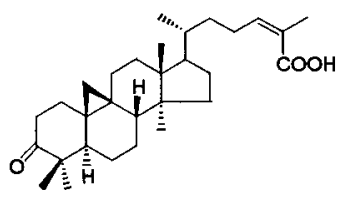
5

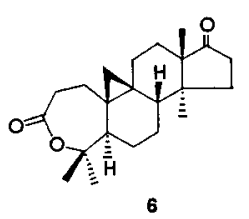

lution electrospray ionization (HR-ESI)-MS $(\mathrm{m} / \mathrm{z} 345.2427$, $[\mathrm{M}+\mathrm{H}]^{+}$), a formula indicating seven degrees of unsaturation. The IR spectrum indicated the presence of ketone $\left(1732 \mathrm{~cm}^{-1}\right)$, carboxylic acid $\left(3550-3250,1703 \mathrm{~cm}^{-1}\right)$, and double bond $\left(1634 \mathrm{~cm}^{-1}\right)$ group. The ${ }^{1} \mathrm{H}$-NMR spectrum (Table 1) showed the presence of an isopropenyl group (methylene protons at $\delta 4.67$ and $4.82, \mathrm{H}-30 \mathrm{a}$ and $\mathrm{H}-30 \mathrm{~b}$; an olefinic methyl group at $\delta 1.71, \mathrm{Me}-29)$ and three tertiary methyl groups $(\delta 0.67,0.82,1.03)$. The ${ }^{13} \mathrm{C}$-NMR spectrum showed signals for 22 carbons, while distortionless enhancement by polarization transfer (DEPT) spectral data indicated the presence of four methyls, eight methylenes, three methines and seven quaternary carbons (including two olefinic carbons, a ketone carbon and a carboxylic acid group). A careful comparison of the ${ }^{1} \mathrm{H}$ - and ${ }^{13} \mathrm{C}-\mathrm{NMR}$ spectra of $\mathbf{1}$ with those of kadsuric acid $(3)^{5)}$ indicated that both of two

Table 1. ${ }^{1} \mathrm{H}$ - and ${ }^{13} \mathrm{C}-\mathrm{NMR}$ Data for Compounds $\mathbf{1}$ and $\mathbf{2}$ in $\mathrm{CD}_{3} \mathrm{OD}^{a)}$

\begin{tabular}{|c|c|c|c|c|}
\hline \multirow{2}{*}{ No. } & \multicolumn{2}{|l|}{1} & \multicolumn{2}{|l|}{2} \\
\hline & $\delta_{\mathrm{H}}($ mult; $J, \mathrm{~Hz})$ & $\delta_{\mathrm{C}}$ & $\delta_{\mathrm{H}}(\mathrm{mult} ; J, \mathrm{~Hz})$ & $\delta_{\mathrm{C}}$ \\
\hline 1 & $1.76 \mathrm{~m}, 2.36 \mathrm{~m}$ & $29.9 \mathrm{t}$ & $1.44 \mathrm{~m}, 2.07 \mathrm{~m}$ & $30.2 \mathrm{t}$ \\
\hline 2 & $1.94 \mathrm{~m}, 2.22$ overlap & $33.6 \mathrm{t}$ & $2.29 \mathrm{~m}, 2.50 \mathrm{~m}$ & $32.3 \mathrm{t}$ \\
\hline 3 & - & $177.8 \mathrm{~s}$ & - & $177.6 \mathrm{~s}$ \\
\hline 4 & - & $148.6 \mathrm{~s}$ & - & $150.6 \mathrm{~s}$ \\
\hline 5 & $2.02 \mathrm{dd}(2.7,10.2)$ & $50.4 \mathrm{~d}$ & $2.55 \mathrm{~m}$ & $46.8 \mathrm{~d}$ \\
\hline 6 & $1.54 \mathrm{~m}, 1.79 \mathrm{~m}$ & $28.8 \mathrm{t}$ & $1.24 \mathrm{~m}, 1.58 \mathrm{~m}$ & $28.2 \mathrm{t}$ \\
\hline 7 & $1.21 \mathrm{~m}, 1.64$ overlap & $26.7 \mathrm{t}$ & $1.29 \mathrm{~m}, 1.51 \mathrm{~m}$ & $24.5 \mathrm{t}$ \\
\hline 8 & $2.22 \mathrm{~m}$ & $42.7 \mathrm{~d}$ & $1.88 \mathrm{~m}$ & $46.9 \mathrm{~d}$ \\
\hline 9 & - & $144.7 \mathrm{~s}$ & - & $22.6 \mathrm{~s}$ \\
\hline 10 & - & $43.1 \mathrm{~s}$ & - & $29.2 \mathrm{~s}$ \\
\hline 11 & $5.36 \mathrm{brs}$ & $118.2 \mathrm{~d}$ & $2.13 \mathrm{~m}, 2.19 \mathrm{~m}$ & $27.3 \mathrm{t}$ \\
\hline 12 & 1.79 overlap, $2.14 \mathrm{~m}$ & $30.8 \mathrm{t}$ & 1.51 overlap, $1.75 \mathrm{~m}$ & $26.1 \mathrm{t}$ \\
\hline 13 & - & $52.4 \mathrm{~s}$ & - & $53.8 \mathrm{~s}$ \\
\hline 14 & - & $43.9 \mathrm{~s}$ & - & $45.5 \mathrm{~s}$ \\
\hline 15 & $1.63 \mathrm{~m}$ & $31.4 \mathrm{t}$ & $1.79 \mathrm{~m}, 1.88$ overlap & $33.0 \mathrm{t}$ \\
\hline 16 & $2.14 \mathrm{~m}, 2.38$ overlap & $34.9 \mathrm{t}$ & $2.25 \mathrm{~m}, 2.46, \mathrm{~m}$ & $35.0 \mathrm{t}$ \\
\hline 17 & - & $223.3 \mathrm{~s}$ & - & $224.2 \mathrm{~s}$ \\
\hline 18 & $0.82 \mathrm{~s}$ & $18.0 \mathrm{q}$ & $1.22 \mathrm{~s}$ & $20.4 \mathrm{q}$ \\
\hline 19 & $1.03 \mathrm{~s}$ & $27.6 \mathrm{q}$ & $\begin{array}{l}\text { 0.42 } \mathrm{ABd}(4.6) \\
0.92 \mathrm{ABd}(4.6)\end{array}$ & $29.9 \mathrm{t}$ \\
\hline 28 & $0.67 \mathrm{~s}$ & $19.8 \mathrm{q}$ & $0.98 \mathrm{~s}$ & $20.3 \mathrm{q}$ \\
\hline 29 & $1.71 \mathrm{~s}$ & $23.8 \mathrm{q}$ & $1.74 \mathrm{~s}$ & $19.9 \mathrm{q}$ \\
\hline 30 & $4.67 \mathrm{brs}, 4.82 \mathrm{br} \mathrm{s}$ & $114.7 \mathrm{t}$ & $4.78 \mathrm{brs}, 4.89 \mathrm{br} \mathrm{s}$ & $112.4 \mathrm{t}$ \\
\hline
\end{tabular}

a) Data were recorded on Bruker $\mathrm{AM}-400 \mathrm{MHz}$ spectrometer $\left({ }^{1} \mathrm{H},{ }^{13} \mathrm{C}\right)$; chemical shifts $(\delta)$ are in ppm; assignments were confirmed by ${ }^{1} \mathrm{H}^{-1} \mathrm{H}$ COSY, HMQC and HMBC 
compounds existed the identical constituting rings $\mathrm{A}, \mathrm{B}$ and $\mathrm{C}$ of which ring $\mathrm{A}$ has suffered an oxidative cleavage between $\mathrm{C}-3$ and $\mathrm{C}-4$. This assignment was confirmed by detailed analysis of the correlation spectroscopy (COSY), ${ }^{1} \mathrm{H}-$ detected heteronuclear multiple quantum coherence (HMQC) and heteronuclear multiple bond connectivity (HMBC) data for 1 (Fig. 1). Thus the structure of $\mathbf{1}$ was proposed as a lanostane derivative.

Two groups of HMBC correlations were observed to establish the structural features of compound 1: one methyl singlet resonance at $\delta_{\mathrm{H}} 0.82$ corresponding to Me-18 showed cross peaks with a ketone carbon $\left(\mathrm{C}-17, \delta_{\mathrm{C}} 223.3\right)$, a methylene $\left(\mathrm{C}-12, \delta_{\mathrm{C}} 30.8\right)$, and two quaternary carbons $\left(\mathrm{C}-13, \delta_{\mathrm{C}}\right.$ 52.4, and $\left.\mathrm{C}-14, \delta_{\mathrm{C}} 43.9\right)$; another methyl singlet resonance at $\delta_{\mathrm{H}} 0.67(\mathrm{Me}-28)$ correlated with a methine $\left(\mathrm{C}-8, \delta_{\mathrm{C}} 42.7\right)$, a methylene $\left(\mathrm{C}-15, \delta_{\mathrm{C}} 31.4\right)$, and also the two quaternary carbons (C-13, C-14). The above observations suggested that $\mathrm{C}$ $12, \mathrm{C}-14$ and $\mathrm{C}-17$ all be attached to the carbon $(\mathrm{C}-13)$ bearing the methyl group, and another quaternary carbon (C-14) bearing the methyl group (Me-28) was situated between $\mathrm{C}-8$ and $\mathrm{C}-15$. HMBC correlations of $\mathrm{H}_{2}-16\left(\delta_{\mathrm{H}} 2.14 / 2.38\right)$ with $\mathrm{C}-14$ and $\mathrm{C}-17$, along with the ${ }^{1} \mathrm{H}-{ }^{1} \mathrm{H}$ COSY spin system, $\mathrm{H}-$ 15-H-16, permitted the closure of the $\mathrm{D}$ ring by linking $\mathrm{C}-16$ with $\mathrm{C}-17$. This connection was further supported by HMBC correlations of the $\mathrm{H}_{2}-15\left(\delta_{\mathrm{H}} 1.62 / 1.65\right)$ with C-14, C-16 $\left(\delta_{\mathrm{C}}\right.$ 34.9) and $\mathrm{C}-17$. The compound (1) was, therefore, represented by octanorlanostane skeleton, with the absence of the side chain at $\mathrm{C}-17$. Furthermore, the $\beta$-orientation of $\mathrm{H}-8\left(\delta_{\mathrm{H}}\right.$ 2.22) was deduced on the basis of rotating frame Overhauser enhancement spectroscopy (ROESY) correlations of Me$19 / \mathrm{H}-8$, Me-18/H-8. In addition, H-5 ( $\left.\delta_{\mathrm{H}} 2.02\right)$ showed no ROESY cross peaks with $\mathrm{H}-8$ and Me-19 suggesting that $\mathrm{H}-5$ was $\alpha$-oriented.

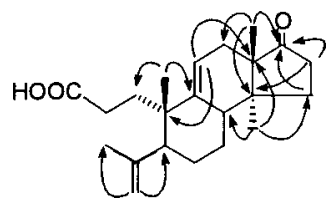

Fig. 1. Key HMBC Correlations of Compound $\mathbf{1}$
The electron impact (EI) spectrum of micranoic acid B (2) provided a molecular ion peak at $\mathrm{m} / \mathrm{z} 344$, the same as that of compound $\mathbf{1}$. The ${ }^{1} \mathrm{H}$ - and ${ }^{13} \mathrm{C}-\mathrm{NMR}$ spectral data of compound $\mathbf{2}$ (Table 1 ) were similar to those of $\mathbf{1}$. The only significant differences included the presence of two up-field quaternary carbon signals at $\delta_{\mathrm{C}} 22.6$ and $\delta_{\mathrm{C}} 29.2$, and the absence of the C-9-C-11 double-bond $\left(\delta_{\mathrm{C}} 118.2,144.7\right)$ and tertiary methyl signal $\left(\mathrm{Me}-19, \delta_{\mathrm{C}} 29.6\right)$.

The differences between compounds $\mathbf{1}$ and $\mathbf{2}$ were established by analysis of ${ }^{1} \mathrm{H}-,{ }^{13} \mathrm{C}-\mathrm{NMR}$ and HMBC data. The ${ }^{1} \mathrm{H}-\mathrm{NMR}$ spectrum of $\mathbf{2}$ exhibited the signals for two proton $\mathrm{AB}$ quartets at $\delta 0.42$ and $0.92(\mathrm{~d}, J=4.6 \mathrm{~Hz})$ due to the characteristic C-19 cyclopropyl methylene protons. This was confirmed by the unusual far up-field quaternary carbon signals at $\delta 22.6$ and $\delta 29.6$ in the ${ }^{13} \mathrm{C}$-NMR spectrum. Furthermore, $\mathrm{H}_{2}-19$ showed HMBC correlations (Fig. 2) with two methylenes: $\mathrm{C}-1\left(\delta_{\mathrm{C}} 30.2\right), \mathrm{C}-11\left(\delta_{\mathrm{C}} 27.3\right)$, as well as with C-8 $\left(\delta_{\mathrm{C}}\right.$ $46.9)$ and $\mathrm{C}-9\left(\delta_{\mathrm{C}} 22.6\right)$ of the ring B. The above spectroscopic evidence revealed that $\mathbf{2}$ differed from $\mathbf{1}$ in which the Me-19 was replaced by a cyclopropyl methylene group. Thus, the structure of compound $\mathbf{2}$ was elucidated as an octanorcycloartane derivative.

The new compounds of $\mathbf{1}$ and $\mathbf{2}$ are highly degraded triterpenes in which fission of the C-17/C-20 bond is achieved via oxidation, while the closest analogue of micranoic acid $\mathrm{B}$ would appear to be buxaheptalactone (6), previously isolated from the roots of Buxus papillosa. ${ }^{8)}$ Chart 1 outlined a potential biogenetic relationship existing between the five compounds. The precursor of the nucleus of micranoic acid A (1) can be envisaged as 4 . Oxidation of the hydroxyl group at $\mathrm{C}$ 3 of $\mathbf{4}$ yields a seven-membered lactone ring- $\mathrm{A}$ intermediate, which is converted to 3 by oxidative cleavage of ring A. Compound 1 could then be formed by oxidative fission be-

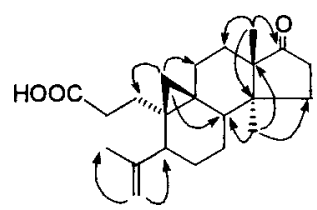

Fig. 2. Key HMBC Correlations of Compound $\mathbf{2}$

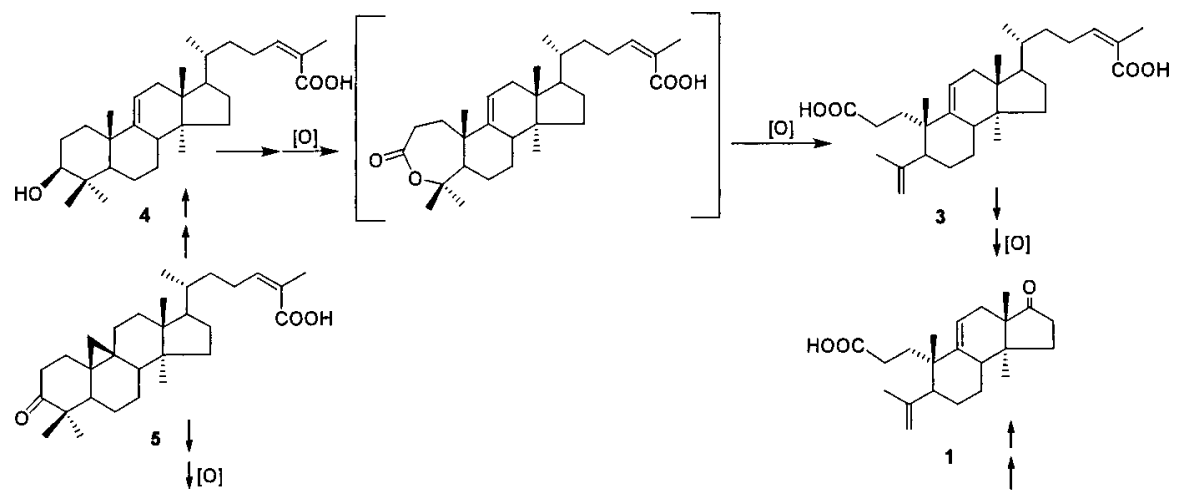

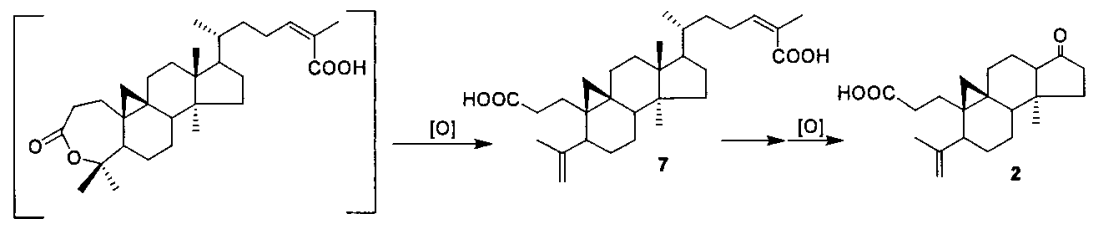

Chart 1. Proposed Biosynthetic Pathway for Compounds $\mathbf{1}-\mathbf{5}$ 
tween $\mathrm{C}-17$ and $\mathrm{C}-20$. In a similar manner, micranoic acid $\mathrm{B}$ (2) could be biosynthesized from 5 as shown in Chart 1. As lanostanes and cycloartanes are biogenetic related, ${ }^{9)}$ compounds $\mathbf{1}$ and $\mathbf{4}$ were then supposed to be derived from $\mathbf{2}$ and $\mathbf{5}$, respectively.

This is the first report of the occurrence of these two unusual octanortriterpenoids isolated from the family Schisandraceae plant.

\section{Experimental}

General Melting points were measured on XRC-1 micro melting point apparatus and were uncorrected. Optical rotations were recorded on a Horiba SEPA-300 High Sensitive Polarimeter. IR spectra were obtained on a BioRad FTS-135 infrared spectrophotometer with $\mathrm{HBr}$ pellets. Mass spectra were obtained on a VG Auto Spec-3000 spectrometer, $70 \mathrm{eV}$ for EI. 1D and 2D NMR experiments were performed on Bruker AM-400 and DRX-500 instruments with TMS as internal standard. Chemical shifts were $(\delta)$ expressed in ppm with reference to the solvent signals. Column chromatography was performed either on silica gel (200-300 mesh, Qingdao Marine Chemical Inc., China) or on silica gel H (10-40 $\mu$, Qingdao Marine Chemical Inc., China). Fractions were monitored by TLC and spots were visualized by heating silica gel plates sprayed with $10 \% \mathrm{H}_{2} \mathrm{SO}_{4}$ in EtOH. HPLC separations were performed on a HP 1100 apparatus equipped with an RI detector and Zorbax SB-C-18 (Agilent, $9.4 \mathrm{~mm} \times 25 \mathrm{~cm}$ ) column.

Plant Material The leaves and stems of Schisandra micrantha were collected in Weisan, Yunnan, People's Republic of China, in November 2001. A voucher specimen was deposited in the Herbarium of the Department of Taxonomy, Kunming Institute of Botany, the Chinese Academy of Sciences and was identified by Prof. Su-Gong Wu.

Extraction and Isolation The air-dried and powdered leaves and stems of $S$. micrantha $(6.8 \mathrm{~kg})$ were extracted three times with $70 \%$ aq. $\mathrm{Me}_{2} \mathrm{CO}$ $(3 \times 201)$ at room temperature for $24 \mathrm{~h}$ and filtered. The filtrate was evaporated in vacuo to give a residue which was suspended in water and partitioned successively with petroleum ether and EtOAc. The petroleum ether extract $(75 \mathrm{~g})$ was separated into four fractions through column chromatograph over porous resin D101 (Chemical Factory of Tianjin University, Tianjin, China) by eluting with water and a gradient mixture of methanol-water from $70 \%$ to $100 \%$. Fractions $3(35 \mathrm{~g})$ eluted by $80 \% \mathrm{MeOH} / \mathrm{H}_{2} \mathrm{O}$ was subjected to column chromatography over $\mathrm{Si}$ gel and the column was eluted with petrol containing amounts of acetone $(1: 0,19: 1,9: 1,8: 2,7: 3)$ to give fractions $3 \mathrm{a}-\mathrm{f}$. Fraction $3 \mathrm{~b}(6.5 \mathrm{~g}$, eluted with $5 \%$ acetone $)$ was chromatographed on $\mathrm{Si}$ gel using petrol-EtOAc $(9: 1)$ as elution to afford 5 (12 mg), as well as mixture of compounds $\mathbf{1}$ and $\mathbf{2}$. The mixture was further chromatographed using RP-HPLC with $70 \% \quad \mathrm{MeOH}-\mathrm{H}_{2} \mathrm{O}$ (flow rate $3.0 \mathrm{ml} / \mathrm{min})$ to yield $93 \mathrm{mg}$ of $1\left(t_{\mathrm{R}} 30 \mathrm{~min}\right)$ and $73 \mathrm{mg}$ of $2\left(t_{\mathrm{R}} 27 \mathrm{~min}\right)$. Fraction $3 \mathrm{~d}$ was chromatographed over $\mathrm{Si}$ gel, eluting with $\mathrm{CHCl}_{3}-\mathrm{MeOH}$ ( $1: 0-100: 1)$ to give $3(25 \mathrm{mg})$ and $4(41 \mathrm{mg})$.

Compound 1: Colourless needles from acetone; mp: $87-88^{\circ} \mathrm{C}$; $[\alpha]_{\mathrm{D}}^{23}+69.11^{\circ}(c=0.25, \mathrm{MeOH}) ; \mathrm{UV}(\mathrm{MeOH}) \lambda_{\max }(\log \varepsilon): 203 \mathrm{~nm}(3.95)$; IR (KBr) cm $\mathrm{cm}^{-1}: 3550-3250,1704$ (br, COOH), $1732(\mathrm{C}=\mathrm{O}), 1651,1634$ $(\mathrm{C}=\mathrm{C})$; EI-MS $m / z$ (rel. int.\%): $344\left[\mathrm{M}^{+}\right.$(73), 329 (34), 311 (10), 301 (18), 283 (16), 271 (87), 245 (72), 227 (22), 203 (23), 185 (20), 173 (23), 163 (62), 145 (50), 133 (41), 119 (70), 105 (68), 91 (62); HR-ESI-MS m/z: $345.2427\left([\mathrm{M}+\mathrm{H}]^{+}\right.$, Calcd for $\left.\mathrm{C}_{22} \mathrm{H}_{33} \mathrm{O}_{3}, 345.2429\right)$; ${ }^{1} \mathrm{H}-$ and ${ }^{13} \mathrm{C}-\mathrm{NMR}$ : see Table 1.

Compound 2: Colourless prisms from acetone; mp: $80-81^{\circ} \mathrm{C}$; $[\alpha]_{\mathrm{D}}^{24}+121.74^{\circ}(c=0.23, \mathrm{MeOH}) ; \mathrm{UV}:(\mathrm{MeOH}) \lambda_{\max }(\log \varepsilon): 202 \mathrm{~nm}(3.69)$; IR (KBr) cm $\mathrm{cm}^{-1}: 3560$-3260, 1703 (br, COOH), $1720(\mathrm{C}=\mathrm{O}), 1645(\mathrm{C}=\mathrm{C})$; EI-MS m/z (rel. int.\%): 344 [M] ${ }^{+}$(79), 329 (85), 311 (25), 301 (26), 271 (66), 245 (46), 163 (71), 133 (65), 119 (94), 105 (100), 91 (86), 81 (55), 67
(36); HR-ESI-MS $m / z$ : $367.2236\left([\mathrm{M}+\mathrm{Na}]^{+}\right.$, Calcd for $\mathrm{C}_{22} \mathrm{H}_{32} \mathrm{O}_{3} \mathrm{Na}$, 367.2249); ${ }^{1} \mathrm{H}$ - and ${ }^{13} \mathrm{C}-\mathrm{NMR}$ : see Table 1 .

Compound 3: Colourless prisms from acetone; $\mathrm{C}_{30} \mathrm{H}_{46} \mathrm{O}_{4}$, EI-MS $m / z$ (rel. int.\%): $470[\mathrm{M}]^{+}$(6), 437 (5), 427 (9), 397 (26), 369 (15), 353 (17), 327 (17), 213 (35), 199 (37), 173 (64), 159 (82), 147 (100), 119 (82), 95 (100); ${ }^{1} \mathrm{H}-\mathrm{NMR}$ (pyridine- $\left.d_{5}\right) \delta: 5.52(1 \mathrm{H}, \mathrm{d}, J=5.3 \mathrm{~Hz}, \mathrm{H}-11), 0.67(3 \mathrm{H}, \mathrm{s}, \mathrm{Me}-$ 18), 1.07 (3H, s, Me-19), $0.98(3 \mathrm{H}, \mathrm{d}, J=6.3 \mathrm{~Hz}, \mathrm{Me}-21), 6.04(1 \mathrm{H}, \mathrm{t}$, $J=7.0 \mathrm{~Hz}, \mathrm{H}-24), 2.13$ (3H, s, Me-27), 0.75 (3H, s, Me-28), 1.80 (3H, s, Me29), $4.95(1 \mathrm{H}, \mathrm{s}, \mathrm{H}-30 \mathrm{a}), 4.89(1 \mathrm{H}, \mathrm{s}, \mathrm{H}-30 \mathrm{~b}) ;{ }^{13} \mathrm{C}-\mathrm{NMR}$ (pyridine- $\left.d_{5}\right) \delta$ : 29.9 (t, C-1), 34.0 (t, C-2), 176.8 (s, C-3), 148.2 (s, C-4), 49.3 (d, C-5), 28.2 (t, C-6), 26.8 (t, C-7), 42.9 (d, C-8), 142.7 (s, C-9), 42.7 (s, C-10), 118.8 (d, C-11), 37.9 (t, C-12), 47.4 (s, C-13), 44.2 (s, C-14), 33.3 (t, C-15), 26.7 (t, C-16), 51.2 (d, C-17), 14.9 (q, C-18), 26.9 (q, C-19), 36.4 (d, C-20), 18.4 (q, C-21), 27.2 (t, C-22), 27.1 (t, C-23), 142.9 (d, C-24), 128.7 (s, C-25), 170.7 (s, C-26), 21.6 (q, C-27), 18.4 (q, C-28), 23.6 (q, C-29), 114.1 (t, C-30).

Compound 4: White powders; $\mathrm{C}_{30} \mathrm{H}_{48} \mathrm{O}_{3}$, EI-MS $\mathrm{m} / \mathrm{z}$ (rel. int.\%): 456 $\left[\mathrm{M}^{+}(65), 441\right.$ (98), 423 (100), 395 (13), 369 (15), 316 (55), 301 (40), 273 (16), 215 (15), 203 (18), 187 (25), 175 (42), 160 (35), 147 (35), 135 (42), $119(55), 95(88)$; ${ }^{1} \mathrm{H}-\mathrm{NMR}$ (pyridine- $\left.d_{5}\right) \delta: 3.53(1 \mathrm{H}, \mathrm{dd}, J=4.3,11.3 \mathrm{~Hz}$, H-3), 5.28 (1H, br d, $J=6.3 \mathrm{~Hz}, \mathrm{H}-11), 0.70(3 \mathrm{H}, \mathrm{s}, \mathrm{Me}-18), 1.09(3 \mathrm{H}, \mathrm{s}, \mathrm{Me}-$ 19), $1.00(3 \mathrm{H}, \mathrm{d}, J=6.8 \mathrm{~Hz}, \mathrm{Me}-21), 6.03(1 \mathrm{H}, \mathrm{t}, J=7.3 \mathrm{~Hz}, \mathrm{H}-24), 2.14(3 \mathrm{H}$, s, Me-27), 0.91 (3H, s, Me-28), 0.99 (3H, s, Me-29), 0.79 (3H, s, Me-30); ${ }^{13} \mathrm{C}-\mathrm{NMR}$ (pyridine- $d_{5}$ ) $\delta: 37.4(\mathrm{C}-1, \mathrm{t}), 27.1(\mathrm{C}-2, \mathrm{t}), 78.0(\mathrm{C}-3, \mathrm{~d}), 39.8(\mathrm{C}-$ 4, s), 53.0 (C-5, d), 21.8 (C-6, t), 28.5 (C-7, t), 42.0 (C-8, d), 149.2 (C-9, s), 39.7 (C-10, s), 115.0 (C-11, d), 36.7 (C-12, t), 44.6 (C-13, s), 47.3 (C-14, s), $34.2(\mathrm{C}-15, \mathrm{t}), 28.3(\mathrm{C}-16, \mathrm{t}), 47.5$ (C-17, d), 18.5 (C-18, q), 22.6 (C-19, q), 36.4 (C-20, d), 21.6 (C-21, q), 28.7 (C-22, t), 26.3 (C-23, t), 142.7 (C-24, d), 128.7 (C-25, s), 170.9 (C-26, q), 18.8 (C-27, q), 28.9 (C-28, q), 14.7 (C-29, q), 18.4 (C-30, q).

Compound 5: White powders; $\mathrm{C}_{30} \mathrm{H}_{46} \mathrm{O}_{3}$, EI-MS $m / z$ (rel. int.\%): 454 $[\mathrm{M}]^{+}$(65), 439 (39), 421 (14), 355 (30), 342 (15), 313 (50), 235 (30), 175 (42), 95 (100); ${ }^{1} \mathrm{H}-\mathrm{NMR}\left(\mathrm{CDCl}_{3}\right) \delta$ : $0.89(3 \mathrm{H}, \mathrm{s}, \mathrm{Me}-18), 0.55(1 \mathrm{H}, \mathrm{d}$, $J=4.3 \mathrm{~Hz}, \mathrm{H}-19 \mathrm{a}), 0.76(1 \mathrm{H}, \mathrm{d}, J=4.3 \mathrm{~Hz}, \mathrm{H}-19 \mathrm{~b}), 0.87(3 \mathrm{H}, \mathrm{d}, J=3.8 \mathrm{~Hz}$, Me-21), 6.07 (1H, t, J=7.6 Hz, H-24), 1.90 (3H, s, Me-27), 1.02 (3H, s, Me28), $1.08(3 \mathrm{H}, \mathrm{s}, \mathrm{Me}-29), 0.97(3 \mathrm{H}, \mathrm{s}, \mathrm{Me}-30) ;{ }^{13} \mathrm{C}-\mathrm{NMR}\left(\mathrm{CDCl}_{3}\right) \delta: 35.5(\mathrm{t}$, C-1), 37.5 (t, C-2), 216.7 (s, C-3), 50.2 (s, C-4), 48.4 (d, C-5), 21.5 (t, C-6), 28.1 (t, C-7), 47.9 (d, C-8), 21.1 (s, C-9), 25.9 (s, C-10), 26.7 (t, C-11), 35.8 (t, C-12), 45.3 (s, C-13), 48.7 (s, C-14), 33.4 (t, C-15), 26.9 (t, C-16), 52.2 (d, C-17), 18.1 (q, C-18), 29.6 (t, C-19), 36.0 (d, C-20), 18.1 (q, C-21), 32.7 (t, C-22), 25.9 (t, C-23), 147.4 (d, C-24), 125.8 (s, C-25), 173.4 (s, C-26), 20.5 (q, C-27), 19.3 (q, C-28), 22.2 (q, C-29), 20.5 (q, C-30).

\section{References}

1) Li L. N., Pure. Appl. Chem., 70, 547-554 (1998)

2) Hancke J. L., Burgos R. A., Ahumada F., Fitoterapia, 70, 451—471 (1999).

3) Sun H. D., Qiu S. X., Lin L. Z., Wang Z. Y., Lin Z. W., Pengsuparp T., Pezzuto J. M., Fong H., J. Nat. Prod., 59, 525-527 (1996).

4) Li R. T., Zhao Q. S., Li S. H., Han Q. B., Sun H. D., Lu Y., Zhang L. L., Zheng Q. T., Org. Lett., 5, 1023-1026 (2003).

5) Liu J. S., Huang M. F., Gao, Y. L., Acta Chim. Sinica, 38, 361-369 (1980).

6) Dai P., Han G. Q., Arison B. H., Chem. J. Chin. Univ., 11, 423-424 (1990).

7) Takahashi K., Tasako M., Chem. Pharm. Bull., 23, 538-542 (1975).

8) Rahman A., Nasir H., Asif E., Ali S. S., Iqabal Z., Choudhary M. I., Clardy J., Tetrahedron Lett., 48, 3577-3584 (1992).

9) Long K. H., Su J. Y., Zheng L. M., Luo Y. K., Zheng Y. Y., Xie S. K., "Chemistry of Terpenoids," High Education Press, Beijing 1985, p. 258. 